\author{
Зорица С. ВИТИЋ \\ Универзитет у Београду \\ Филолошки факултет \\ Катедра за српску књижевност са \\ јужнословенским књижевностима
}

\title{
АТОНСКИ УЗОРИ ТЕОДОСИЈЕВИХ ЖИТИЈА
}

\begin{abstract}
Теодосије Хиландарац показује изузетно познавање свих темељних списа хришћанско-византијске књижевности, од светоотачке традиције, св. Атанасија Александријског, св. Григорија Богослова и св. Јована Лествичника, до житија најстаријих светогорских подвижника - св. Петра Атонског (IX век) и св. Атанасија Атонског (X век). Било да је у питању једино српско анахоретско житије, Житије св. Петра Коришког, било да је то животопис првог српског архиепископа, уочљиви су утицаји атонске лектире којом се Теодосије извесно надахњивао. У раду се разматрају вишеслојни трагови ових житија у Теодосијевим делима - схватање светости, монаштва, заједничког подвига, пустиње, поетичких законитости, па и неке занимљиве појединости и формулације очигледно преузете из ових текстова.

Кључне речи: Теодосије Хиландарац, житија, св. Петар Атонски, св. Атанасије Атонски.
\end{abstract}

Литерарне представе светитељског подвига дубоко су условљене расправама о исправности, вредности и дометима различитих концепција монаштва, које сежу у најраније године хришћанства ${ }^{1}:$ аскетско практиковање врлине наспрам киновије (општежића) - најраспрострањенијег облика монаштва. ${ }^{2}$

Усамљивање у пустињи ради поста и молитве пракса је првих монаха у Египту, Сирији и Палестини. Тај реални простор убрзо постаје симбол неметежног живота, аскезе и духовног усавршавања. Међутим, двоструку вредност пустиње ${ }^{3}$ илуструје

"zv2207@gmail.com

${ }^{1}$ Праузор аскетских искушења јесте кушање Христа (Мт 4,1-11), а молитвено усамљивање није реткост у Светом писму (Мк 1,35; Лк 5,16). И киновијско монаштво има своје новозаветне моделе: реч је о првим хришћанима који „бијаху постојани у науци апостолској, и у заједници, и у ломљењу хљеба, и у молитвама” (Дап 2,42), у којих „бјеше једно срце и једна душа; и ниједан не говораше за своје имање да је његово, него им све бјеше заједничко" (Дап 4,32).

${ }^{2}$ Преглед најважнијих светоотачких становишта о овом темељном питању, са новијом литературом, доноси Џејмс Мантра (Manthra 2015: 1-35).

${ }^{3} \mathrm{O}$ амбивалентном односу према пустињи у Светом писму и раној аскетској литератури в. Guillaumont 1975: 3-21. 
већ Житије св. Антонија. Испосниково станиште тамо је пуста тврђава пуна гмаза, поприште демонских напада (12,3-4), а с друге стране, св. Атанасије Александријски даје идиличну слику монашког живота у египатској пустињи: „њихове келије биле су у планинама, попут шатора где станују божански хорови, који певају псалме, уче Писмо, посте, моле се, које весели нада у будуће доба, који раде да би дали милостињу, и чувају љубав и слогу међу собом" $(44,2)$; следи цитат из књиге Бројева, 24,5-6: „пружили су се као потоци, као вртови крај ријеке, као мирисава дрвета која је посадио Господ, као кедри на води" (Атанасије Александријски 2014: 151-152).

После св. Антонија, умножавањем монашких заједница, пустиња ће заиста постати град - desertum civitas. Још један оксиморон - desertum floribus vernans (пустиња процвала цвећем) ${ }^{4}$, како каже св. Јероним (Laus eremi, PL 22,353; EA 1930: 275), представља остварење Исаијиног пророштва 35,1 : „Радоваће се томе пустиња и земља сасушена, веселиће се пустош и процвјетати као ружа". Појам пустињеграда ${ }^{5}$ осим духовног има и материјални смисао - доласком хиљада монаха ови су неплодни предели доиста процветали. Рајски предео, али и место искушења, пустиња се преображава, у зависности од географских и историјских условљености (Le Gof 1999: 73-79).

У XIV писму св. Василија Великог, упућеном св. Григорију Богослову (Назијанзину), налази се ентузијастички опис усамљеничког живота. Док трага за смирењем, Господ му открива идеално место за подвиг. Следи врло развијен locus amoenus - ливада испресецана прозирним потоцима, окружена планинама и шумом, изолована као острво, уз то цветна, освежена поветарцем с вода, а тишину која на њој влада ремети једино цвркут птица (Basile de Césarée 1957: 42-45). ${ }^{6}$

Међутим, свим кападокијским оцима заједничко је гледиште да је боравак у пустињи само једна од три животне фазе монаха, сасвим неподесна за студије и бављење науком (Guillaumont 1975: 9). Знатно склонији киновијском моделу, св. Василије, према Григорију Богослову (62), ипак проналази компромисно решење:

\footnotetext{
„Он их је међусобно помирио и одлично један у други уклопио; изградио је, истина, бројне пустињачке ћелије и манастире, али не негде далеко од општежитељних и мешовитих заједница, нити их је било каквим зидом оградио и једне од других раздвојио, него напротив, приближио их је и чврсто повезао, зато да живот у подвигу не био потпуно изолован, као и да делатни живот не би био сасвим без подвига, него да као земља и море своје дарове међусобно измењују и да тако заједнички јединственој слави Божјој допринесу” (Григорије Богослов 2001: 173).
}

Оваква замисао могла је бити основ настајања различитих облика усамљеништва, а оживљена је и у првим монашким заједницама на Светој Гори. Наиме, на Атосу се сасвим ретко срећу подвижници који су читав свој век провели у тиховању (изузетак је св. Петар Атонски); најчешће се, након достизања високог ступња мо-

\footnotetext{
${ }^{4}$ Bartelink 1973: 7-15.

${ }^{5}$ О топосу пустиње као слике небеског Јерусалима в. Popović 2009: 151-175.

${ }^{6}$ Слично св. Јероним 376. године из Сирије пише пријатељу Хелиодору (EA 1930: 275) одушевљен животом у пустињи (чисто, светло небо, блискост с Богом; супротност томе је задимљени градски затвор). Оваква слика пустиње потврђена је и у Житију св. Павла Тивејског, 5 (PL 23, col. 21): „Најзад наиђе на стеновито брдо, подно којега беше невелика пећина затворена каменом. Уклонивши камен [...], он угледа голему одају отворену к небу, закривену широком крошњом једне старе палме, а унутра беше бистар извор, чију тек потеклу воду ту одмах, кроз омањи процеп, гуташе земља што је роди".
} 
нашког савршенства, враћају у свет да би своје духовно искуство ставили у његову службу. Ипак, током столећа, појединци или скупине отшелника подвизавали су се на атонском тлу, мање или више везани за поједине манастире (Папахрисанту 2003: 31-41). Такву Свету Гору у настајању већ почетком XI века описује хагиограф Атанасије, писац пространог Житија св. Атанасија Атонског , оснивача Лавре (38, $1-8)$ :

„Чим се, дакле, попе на Гору, Атанасије обиђе сва места и истовремено осматраше подвижнике који ту живљаху и којих тада не беше много. Пошто пажљиво испита њихово тешко живљење, усамљенички живот не од овога света, дивљаше им се и наслађиваше се њима и вероваше уистину да је досегао вечне горе" (Noret 1982: 18-19; Вељковић 2012: 63).

Како ова наталожена, често противречна литерарна традиција утиче на слику подвижништва у Теодосијевим житијима?

Иако је извесно да је житија атонских светитеља наш писац читао у оригиналу, jep преписи превода нису старији од средине XIV века ${ }^{8}$, а најстарији светогорски потиче из XV столећа (Иванова 2008: 577), ипак се за поређења овог типа најподесније чинило користити текст словенског превода Житија св. Атанасија Атонског (ЖАА). Превод је, по свему судећи, настао према млађем Другом житију (Noret 1982: CXLIX). У недостатку издања служимо се српским преписом из светогорског манастира Пантелејмона бр. 22 (П22), из прве четвртине XV века (Шпадијер 2014: 267-274) и Даничићевим издањем Теодосијевог Житија св. Саве (ЖС) 9

Сличности започињу од првог призора који се указује двојици светитеља - дуго прижељкивани Атон испуњен мноштвом подвижника:

ЖАA, VITA B 13, 1-8 (Noret 1982: 139); П22, 10a

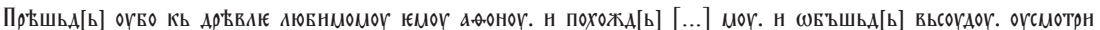

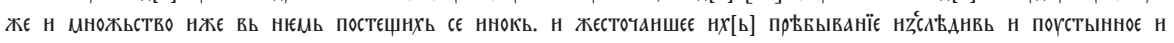

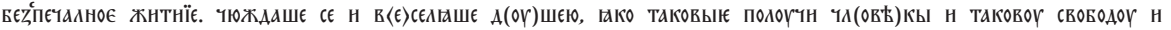
оүстроєнїє, Єжє н прҺжАє сєГО жєАадшє.

ЖС, 22-23

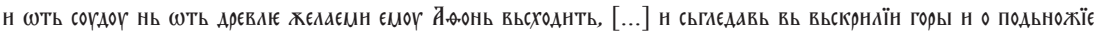

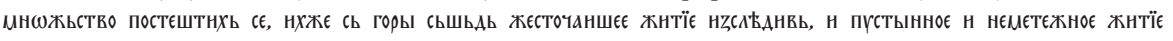

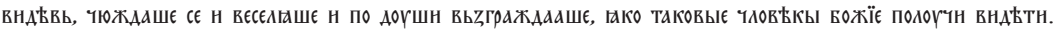

Следи опис њиховог побожног живота, лишеног свега световног и материјалног:

ЖАA, VITA В 13, 8-14 (Noret 1982: 139); П22, 106

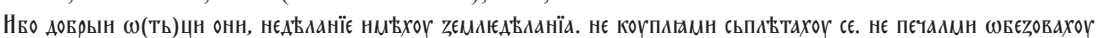

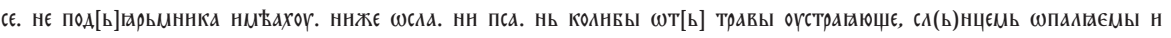
мраzомь помрьzающе.

\footnotetext{
${ }^{7}$ Прво житије (Vita A) настало је убрзо после светитељеве смрти (око 1001), а најкасније око 1025. године, а друго, анонимно (Vita B), између 1028. године и краја XI века (Свети Атанасије Атонски 2012: 30). Издање: Noret 1982: 1-125; 127-213.

${ }^{8}$ Бугарски препис НБКМ 307 (Цонев 1910: 248-249). О новом датирању в. Иванова 1991: 125.

${ }^{9}$ Теодосије Хиландарац 1973: 1-221.
} 
ЖС, 23-24

нБ$\omega$ доБрын

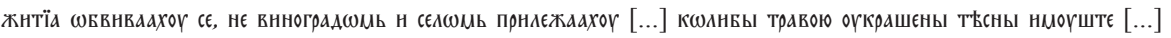

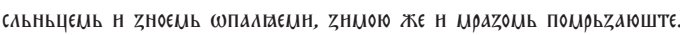

Теодосијева похвала светогорским пустињацима, различито од ЖАА, али сасвим у складу са пређашњом традицијом, подвижничко станиште претвара у неодољив рајски предео, у којем су се монаси угнездили попут морских птица:

„Фвы оүБ

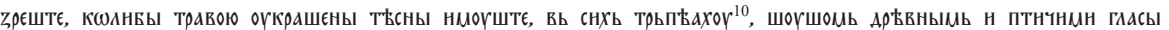

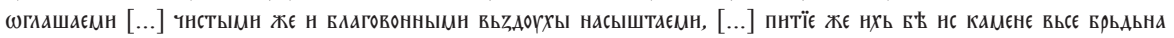
сладка текоүштї̈ вода нжє жєждоү оүврачююштн” (Теодосије Хиландарац 1973: 23-24).

Дакле, locus amoenus као место трпљења - и опет је само једном речју оцртан стари, вечити парадокс ${ }^{11}$.

Овакво беспорочно, безметежно, бесплотно и бестелесно живљење Теодосије, као и многи његови знаменити претходници, види као готово анђеоско: иако због тела и није згодно да се зову анђели, уистину бејаху Божји људи (аштє н нњсть полzа

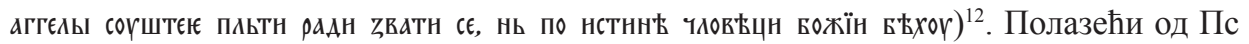
8,5 , где се хвала Господу узноси због изузетног и непрекидног старања о човеку: „Учинио си га мало мањега од анђела, славом и чашћу вјенчао си га”, већ св. Јован Златоусти (Adversus oppugnatores vitae monasticae 3,11; EA 1930: 210-211) једнакост, хармонију, слогу и марљивост која влада међу анђелима упоређује са монашким заједницама, а св. Јован Лествичник у XV поуци каже: „Ко је победио тело, победио је природу. А ко је природу победио, постао је, без сумње, натприродан. Такав човек је само нешто мало - да не кажем нимало - мањи од анђела" (Богдановић 1988: 161).

У Житију св. Саве сцена заједничког подвига оца и сина једна је од развијенијих; упечатљива, емотивна и дирљива, она делује сасвим јединствено и оригинално; међутим, њена окосница постоји и у Житију св. Атанасија Атонског. У питању је почетак светитељевог подвизавања уз непознатог старца покрај Зига, једног од најстаријих светогорских манастира:

ЖАA, VITA В 14, 19-23 (Noret 1982: 140); П22, 186

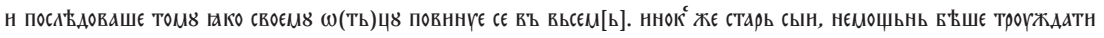
сє. юноША ЖЕ НСПльннашє АНШєНїє старЦа.

ЖC, 44

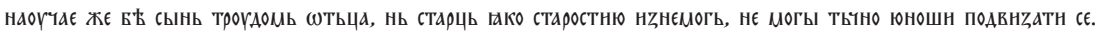
юноша Жє напАьнюашє Аншєнїє старца.

\footnotetext{
${ }^{10} \mathrm{Y}$ нешто другачијој варијанти словенског превода ЖАА доследно је пренесен грчки оригинал -

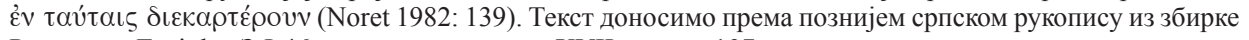
Радослава Грујића, 3-I-46, из друге четвртине XVII века, л. 107a: мноzн жє н колнгн

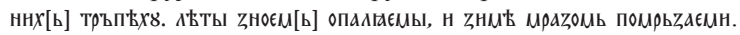

${ }^{11} \mathrm{O}$ дивљој и неприступачној пустињи св. Петра Коришког као „дивном од Бога за отшелнике устројеном пребивалишту” в. Витић-Недељковић 1999: 147. Представе искушења у пустињи у словенским литературама разматра Dziadul 2008: 31-38.

${ }^{12}$ Теодосије Хиландарац 1973: 23.
} 
Поред оваквих директних подстицаја, Теодосије се надахњивао Атанасијевим житијем и на стилском плану: префињен, згуснут, елегантан, уједно и једноставан стил, изненађујући реченични обрти, снажни контрасти, изузетна реторичност, али и вешто уобличавање драматичних сцена одлика су грчке хагиографије, која подражава великом узору, Григорију Богослову, чије беседе су на много места директно цитиране (Вељковић 2012: 31). Местимична лиричност, емотивност и упадљива ангажованост аутора Житија св. Атанасија, који свог дивљења достојног јунака свестрано приказује, Теодосију, писцу сличног сензибилитета, морале су бити посебно привлачне.

Сасвим су другачији утицаји Житија св. Петра Атонско2 ${ }^{13}$, типичне хагиографије, без много историјских података, у којој је преко педест година светитељевог повижништва испуњено визијама, чудима и, нарочито, искушењима и демонским нападима. Природно, таквав текст могао је пре бити узор за житије првог српског анахорете, Петра Коришког - од стандардне уводне поетичке формулације, преко градацијског представљања демонских напада, до инспирације за изузетну, у Житију св. Петра Корииког потпуно трансформисану сцену - појаву арханђела Михаила као божанског помоћника наоружаног мачем.

Од античких времена сврха књижевног стварања заснивала се на двама опречним принципима: prodesse et delectare. И Никола, писац Житија св. Петра Атон$c \kappa о 2^{14}$, и Теодосије Хиландарац, следећи дотадашњу византијску хагиографију, а преко ње античку грчку, превасходно хеленистичку књижевну традицију (уп. Шпадијер 2010: 249-260), ове принципе преносе и експлицитно их изражавају у уводима својих житија, посебно наглашавајући корист коју писци посредно стичу од користи својих слушалаца:

ЖПА, 1.1. (Lake 1909: 18); Хил. 463, 38а

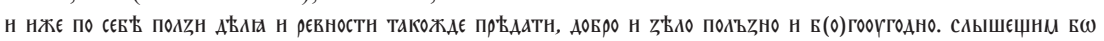

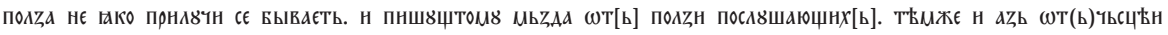

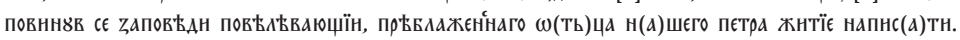

ЖПК, 305-306

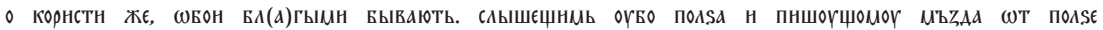

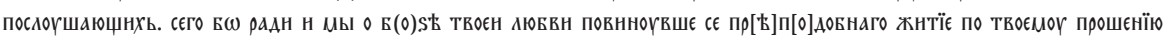
скаZатн начннає.

Када је у питању приказ места подвига, свети Петар Атонски налази богосаздану пештеру „веома мрачну, сву зараслу у дубоко грмље, у којем беше гомила гмаза [...] а ту се гнежђаше и мноштво демона" (ЖПА 4.1, Lake 1909: 26). Недостатак светла, непријатељско растиње и животиње у окружењу атонског подвижника представљају непосредан увод у низ демонских искушења.

${ }^{13} \mathrm{O}$ атонском подвижнику Петру, чије су чудотворне мошти пронађене почетком IX века, дознајемо из Житија, које је знатно доцније, највероватније пре краја Х века, написао светогорски монах Никола. Издање: Lake 1909: 18-39.

${ }^{14}$ Словенски превод заступљен је у рукописима од друге половине XIV до средине XVII века, а најстарији светогорски је из друге половине XV столећа (Иванова 2008: 544). Такође неиздат, превод Житија св. Петра Атонског (ЖПА) доносимо према српском рукопису из XV и са почетка XVI века (Хиландар бр. 463, в. Генадије Светогорац 1995: 12-16), а Житије св. Петра Коришког (ЖПК) према Шпадијер 2014: 301-353. 
У овај оквир уклапа се и пустиња Петра Коришког; међутим, Теодосијева слика знатно је развијенија, проширена описом аскетског „свакодневног мучеништва” ${ }^{15}$. Но, и ту наш писац налази додатни ослонац у својој богатој лектири: попут св. Василија Великог ${ }^{16}$, ни Петар нема ништа „осим поцрнела тела и на њему нужних (худих) рубина власених, па и то ради прикривања удова" (раzвь отрьньвша тъдл, н на нІемь ноүждныхь (худныхь) рогвь власьныхь. н сїє прнкръвєнїа радн оүдовь, Шпадијер 2014: 316). Сличности постоје и у опису поста: оба светитеља, немилостиви, незгодни и непоштедни непријатељи својега тела, били су „бесхлебни - мало речено - као да су бестелесни" 17 (вєспнщьн жє, мало рєщн ғако вєппхътінь, Шпадијер 2014: 316). Најзад, и Григорије Богослов и Теодосије бирају исту јеванђељску поуку (Мт 6,28) да би оцртали истинску подвижничку бригу за душу, која изискује потпуну небригу за тело: тако се св. Василије „на кринове и птице небеске угледао” (Григорије Богослов 2001: 172), док се св. Петар „радоваше умно посматрајући кринове у пољу” (на крнны во сєльныє оүино въzнрає, Шпадијер 2014: 317).

Да се вратимо демонским појавама у Житију св. Петра Атонског. Представљена су четири напада: прва два су типични насртаји мноштва наоружаних демона, отровних гмизаваца или дивљих звери које покушавају да усмрте Светога (ЖПА 2, 3, Lake 1909: 27), док трећи и четврти представљају лукаве ђавоље преображаје. У покушају да преласти Петра, ђаво се прво јавља као један од његових вољених слугу, који жели да у њему подстакне сећање на ближње (ЖПА 4, Lake 1909: 28), док је следећи његов преображај још импресивнији - пред улазом у пештеру стоји арханђео са исуканим мачем, који претераним похвалама покушава да Светог одврати од пустиње:

ЖПА 5, Lake 1909: 29; Хил. 463, 556

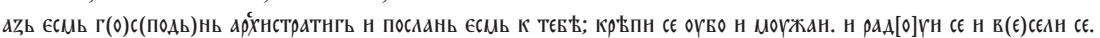

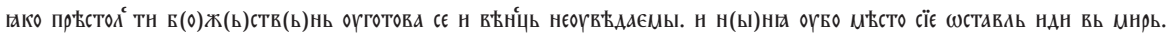

Ово последње велико искушење разрешено је појавом Богородице (ЖПА 6, Lake 1909: 30) и анђела који у наредне педесет три смирене године подвижниковог живота редовно долази доносећи му небеску храну.

Врсту и интензитет Петрових страдања у пустињи Теодосије описује с нарочитом поступношћу и по прецизном плану, а с једнаком правилношћу смењују се физичке и духовне патње. Као први непријатељ подвижников јавља се змија, коју савладава уз Михаилову помоћ, потом следи демонско искушавање сестриним гласом, зверски напади различитог интензитета, застрашујући призор ђавоље војске, коју Петар одагнава уз помоћ божјег анђела, и коначно, претворно обраћање „главног међу бесовима" 18 , које би требало да подстакне пустињакову гордост, једну од наопаснијих страсти, јер, према св. Јовану Лествичнику (Поука XXIII), „гордоме монаху демон није потребан: он је самоме себи постао демон и непријатељ” (Свети Јован Лествичник 1988: 190).

\footnotetext{
${ }^{15}$ Формулација из Житија св. Антонија $(47,1)$. О схватању односа између монашког подвига и мучеништва у традицији која претходи Житију св. Петра Коришког в. Витић-Недељковић 1999: 150.

${ }^{16}$ „Шта је овај овде икада имао, до тело своје и најнужније одело да голотињу сакрије?” (Григорије Богослов 2001: 171)

17 „А ко је још на мање хране живео, и такорећи без тела опстајао?” (Григорије Богослов 2001: 172).

${ }^{18}$ О овој демонској беседи детаљније у Витић-Недељковић 1999: 151.
} 
Сцена двоструког напада - старца са мочугом и арханђела са мачем - представља прву велику победу св. Петра Коришког, а у Михаиловом обраћању најављене су пустињакове бројне борбе са демонима, након којих ће их коначно посрамити и отерати:

ЖПК, 324

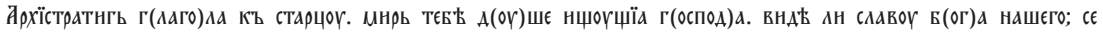

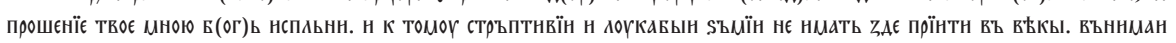

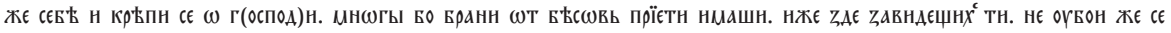

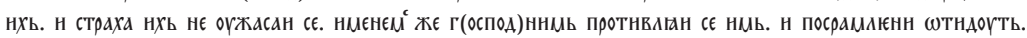

Како је култ арханђела Михаила посебно био распрострањем међу пустиножитељима ${ }^{19}$, због анђеоског живота на земљи и свесрдне помоћи коју им Господ често шаље преко анђела, не чуди његова улога у житијима атонског и српског подвижника. Међутим, колико год је ефектно формулисана завршна демонска беседа коју у Житију св. Петра Атонског изговара лажни арханђел Михаило, Теодосије свој узор ипак надмашује врхунским тематско-мотивским повезивањем - Михаило, божји изасланик, у свом обраћању антиципира све будуће догађаје, а завршна победа св. Петра Коришког, након које му постиђени демони узносе наговештај похвале („О, невољо! О, ти, Петре, тврда стено! Одоле каменим трпљењем својим, одоле и победи!"”) ${ }^{20}$, нашем писцу омогућава да својом похвалом складно заокружи животопис подвижника „именом тврдог и животом”.

\section{Скраћенище}

EA 1930: Enchiridion Asceticum. Loci SS. patrum et scriptorum ecclesiasticorum ad ascesim spectantes quos collegerunt M. J. Rouët de Journel S. J. et J. Dutilleul S. J., Freiburg: B. Herder Book Company, 1930.

PL 23: Hieronymus, Vita Pauli (ed. J.-P. Migne, post. R. Khazarzar), Patrologiae cursus completus. Series latina. Vol. 23. Paris 1845, 17-28. <http://www.patrologia-lib.ru/ patrolog/hieronym/vita_pau.htm.> 19.01.2018.

\section{Извори}

Атанасије Александријски. Житије светог Антонија. Превод, предговор и коментари Данијел Дојчиновић. Бања Лука: Филолошки факултет, 2014.

Григорије Богослов. Надгробно слово Великом Василију уз митолошка тумачења аве Нона. Предговор, превод и белешке Челица Миловановић. Глас САНУ, CCCLXXXIX, књ. 18. Београд: Српска академија наука и уметности Одељења језика и књижевности (2001): 129-195.

\footnotetext{
${ }^{19}$ То потврђује и живопис цркава других балканских испосника. Наиме, у XIV веку обновљене цркве над гробовима св. Прохора Пчињског и св. Гаврила Лесновског биле су посвећене арханђелима (Тодић 1998: 196).

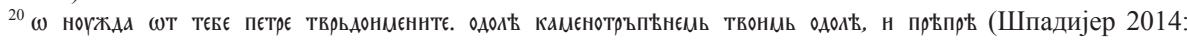
$337-338)$
} 
Свети Атанасије Атонски. Увод. Житије. Коментари. Превод са грчког Марина Вељковић. Краљево: Манастир Жича, 2012.

Свети Јован Лествичник. Лествица. Превод са грчког, предговор и коментари Димитрије Богдановић. Увод Милорад Лазић. 2. изд. Београд: Сфаирос, 1988.

Теодосије Хиландарац. Живот светога Саве. Издање Ђуре Даничића 1860. Приредио и предговор написао Ђорђе Трифуновић. Београд: Ђ. Трифуновић, 1973.

Шпадијер И. Свети Петар Коришки у старој српској књижевности. Београд: Чигоја штампа, 2014.

Basile de Césarée. Lettres, XIV. Éd. Yves Courtonne, I. Paris: Les Belles Lettres, 1957: $42-45$.

Lake K. "Appendix to Chapter I: The Life of Peter the Athonite." The Early Days of Monasticism on Mount Athos. Oxford: Clarendon Press, 1909: 18-39.

Noret J. Vitae duae antiquae Sancti Athanasii Athonitae. Corpus Christianorum, Series Graeca 9. Louvain: Brepols-Turnhout, 1982.

\section{Литература}

Витић-Недељковић 3. „Демонска искушења у Теодосијевом „Житију св. Петра Коришког." Научни састанак слависта у Вукове дане, 28/1 (1999): 143-153.

Генадије Светогорац. Служба светом Петру Атонском. Приредио Ђорђе Трифуновић. Крушевац: Багдала, 1995.

Dziadul P. „Мотив „искушења у пустињи” у словенској житијној књижевности.” Прилози за књижевност, језик, историју и фолклор, књ. 74 (2008): стр. 31-38.

Иванова К. „Новоизводните търновски сборници и въпросът за ролята на Патриарх Евтимий в техния превод.” Старобългарска литература, књ. 25-26 (1991): $124-134$.

Иванова К. Bibliotheca Hagiographica Balcano-Slavica. София: Академично издателство „Проф. Марин Дринов”, 2008.

Папахрисанту Д. Атонско монаштво. Почеции и организащија. Београд: Друштво пријатеља Свете Горе Атонске, 2003.

Тодић Б. „Одраз култа светог Петра Коришког у уметности.” Манастир Црна ријека и свети Петар Коришки. Уредник Драгиша Бојовић. Приштина- Београд: Друштво пријатеља манастира Црна ријека (1998): 189-204.

Цонев 1910: Цонев Б. Опис на ръкописите и старопечатните книги на Народна библиотека в София, I, София: Народна библиотека, 1910.

Шпадијер И. „Антички корени Теодосијеве поетике.” Зборник Матице српске за књижевност и језик, књ. LVIII/2 (2010): 249-260.

Шпадијер И. „Пантелејмон 22 - један необичан српски зборник из првих деценија XV века." Афон и славянский мир, Материалы международной научной конференции, посвященной 1000-летию присуствия русских на Святой Горе (Белг- 
рад, 16-18 мая 2013). Издание русского Свято-Пантелеимонова монастыря на Афоне, Святая гора Афон (2014): 267-274.

Bartelink G. J. M. „Les oxymores desertum civitas et desertum floribus vernans.” Studia monastica, 15 (1973): 7-15.

Guillaumont A. „La conception du désert chez les moines d'Egypte.” Revue de l'histoire des religions, t. 188, $\mathrm{n}^{\circ} 1$ (1975): 3-21.

Le Gof Ž. Srednjovekovno imaginarno. Ogledi. Prevela s francuskog Ivanka Pavlović. Sremski Karlovci-Novi Sad: Izdavačka knjižarnica Zorana Stojanovića, 1999.

Manthra J. „Anachoresis. The Legacy of "Withdrawal” in the Desert Fathers.” 1-35. Academia.edu. <https://www.academia.edu/15485263/Desert_Spirituality.> 12. 11. 2017.

Popović D. "Desert as Heavenly Jerusalem: the imagery of sacred space in making." New Jerusalems. The translation of sacred spaces in christian culture. Ed. A. M. Lidov. Moscow: Indrik (2009): 151-175.

Zorica S. Vitić

ATHONITE LITERARY HERITAGE IN THEODOSIOS' VITAE

Summary

The paper deals with some of the influences of the most imortant Byzantine patristic authors (St Athanasios of Alexandria, St Gregory the Theologian, St John Klimax) on Theodosios' Life of St Sava and Life of St Peter of Koriša, with the main focus on the contribution of the early Athonite Vitae, of St Peter the Athonite and of St Athanasios the Athonite. The work of Theodosios proves to be so deeply rooted in tradition that not only the inherent conception of ascetic life but also the presence and shaping of some episodes or even details cannot be explained without repeated reference to the Athonite literary heritage.

Key words: Theodosios from Chilandar, Vitae, St Peter the Athonite, St Athanasios the Athonite. 